\title{
Box-scheme as alternative food network - the economic integration between consumers and producers
}

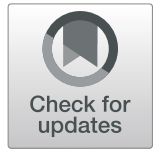

\author{
Ronaldo Tavares de Souza(B)
}

\author{
Correspondence: ronaldo.tavares- \\ de-souza.1@ulaval.ca; \\ ronaldotavaresdesouza@gmail.com \\ PhD candidate in Geographic \\ Sciences, Université Laval, Québec, \\ Canada
}

\begin{abstract}
As a growing option for small farmers, alternative food networks (AFN) have attracted the attention of researchers around the world. Nevertheless, not much focus is given to box-schemes as a format itself. The nomenclature is often associated with community-supported agriculture (CSA) and solidarity purchase groups (SPG), but many companies have reduced geographic and informational distances without demanding such a narrow relationship between collaborators. The aim of this article is to analyze the relationship between companies and their customers. A theoretical framework was built based on thoughts about economic integration and the relationship in the retail environment to examine the possibility of reciprocity and redistribution. The fieldwork was conducted in São Paulo, Brazil. Technology is found to be fundamental to the rise of such companies, but the Internet is not the only key, the telephone is also important for a warmer and closer relationship. The interviews revealed different signals of reciprocity supporting a trusting relationship while the occasional buyers demonstrate more opportunistic behaviors. Of the cases studied, one successful company demonstrated signs of reciprocity between companies and customers, as well as customer integration based on redistribution characteristics. This confirmed the possibility of the boxscheme contributing to rural sustainability, related to customers who have built a broader perspective, going beyond price and quality. The article concludes defending that this format of commerce should be further studied to confirm its capacity to support rural development and continue to deepen the understanding of the conditions that can make it successful.
\end{abstract}

Keywords: Alternative food network, Box-scheme, Rural development, Food retail, Responsible consumption

\section{Introduction}

The growth of organic food sales has not stopped and it is still an option to provide higher income to small producers (IFOAM 2005; Luttikholt 2007). Nevertheless, the conventionalization of this market is a serious threat to the improvement of economic conditions of such farmers (Blank and Thompson 2004). Many authors say that the increasing barriers represented by regulation, health standards and trade practices force

(c) The Author(s). 2020 Open Access This article is licensed under a Creative Commons Attribution 4.0 International License, which permits use, sharing, adaptation, distribution and reproduction in any medium or format, as long as you give appropriate credit to the original author(s) and the source, provide a link to the Creative Commons licence, and indicate if changes were made. The images or other third party material in this article are included in the article's Creative Commons licence, unless indicated otherwise in a credit line to the material. If material is not included in the article's Creative Commons licence and your intended use is not permitted by statutory regulation or exceeds the permitted use, you will need to obtain permission directly from the copyright holder. To view a copy of this licence, visit http://creativecommons.org/licenses/by/4.0/. 
these farmers to engage with alternative food networks (AFN) as the only option to commercialize their products (Cicatiello et al. 2015; Micheels and Boecker 2017; Wilkinson 2010). The same is considered by Goldberger (2011), who proposes a bifurcation where small farm holders follow AFN and large farmers supply the conventional super and hypermarkets.

There is not yet a clearly accepted definition along the discussion that defines what an AFN is, and the most often found proposal defines it in opposition to the conventional super and hypermarket model (Forssell and Lankoski 2015; Si, Schumilas, and Scott 2015; Tregear 2011; Wilson 2013). This includes farmers' markets, communitysupported agriculture (CSA), and solidarity purchase groups (SPG), among other formats. I also highlight that many articles overlap with similar research areas, such as short food supply chain and local food systems. Another way to conceptualize AFN is as an expression of recursive material and symbolic interactions between producers and consumers (Goodman, DuPuis, and Goodman 2012). These all combined have formed an area of growing attention while more and more researchers are turning their focus to contribute to its development.

Its importance relies on the fact that AFN development could bring more sustainable practices, socio-economically and environmentally, to food production (Mastronardi et al. 2015). Fonte (2013), based on several authors, questions if they are fairer and more sustainable pre-figurative ways of political models of consumption. This is because the sustainability is assumed from a closer relationship between producers and consumers in opposition to the distance established in the conventional chain (Cicatiello et al. 2015; Hayden and Buck 2012; Hunt 2007; Lass, Lavoie, and Fetter 2005; Thilmany 2008; Vermeir and Verbeke 2006). Shorter distances involve not only the geographic dimension, but also informational gaps. It is assumed that, as far as consumers can make a more informed decision mediated by trusted sellers, their choice would be influenced by sustainability values (Baldi et al. 2019). Alterity is not a guarantee of sustainable practices, though, as localism can result in elitism and reactionism (Hinrichs 2003). The proximity may strengthen the influence of social embeddedness on their purchase decision (Granovetter 1985; Hinrichs 2000). Brinkley (2017:315) considers the "food supply chain as means of spatially distributing social values by leveraging economic capital" so, its social embeddedness creates feedback loops that concentrate economic and social capital.

The recent growth of AFNs may also be related to modern information technologies. Nowadays, the cost of communication is so low compared to previous decades that it enables many small entrepreneurs to advertise broadly with low investment (Bos and Owen 2016). Groups of people can also find and connect with each other much more easily using instantaneous messages (Thorsoe and Kjeldsen 2016). Virtual communities facilitate the flow of information across social networks, and artificial intelligence mechanisms can even automatically connect people to topics and people that interest them. Therefore, virtual reality is part of the continuity of the human evolution (Castells 2000). It is neither separated nor distant from what is already known about human relationships, but a new tool that enables new communication formats and flow of meanings (Sykes 2005).

A review of the literature has shown that box-schemes are one of many different AFN models, but they have received less attention from researchers. Paul e McKenzie 
(2013) define box-scheme as a home delivery system of fresh fruits and vegetables with seasonal assortment, usually delivered weekly and paid for in advance. Brown et al. (2009) adds the possibility of central delivery points instead of home delivery. In Mastronardi et al. (2015:1), it is described as "sales method whereby the farmer sends produce directly to the homes of participating consumers." But we also find it as composed by products from different farmers (Milestad, Kummer, and Hirner 2017) as the practice gains scale and reaches over 60,000 people with large companies operationalizing box-schemes in the UK. Hashen et al. (2018:1600) define box-scheme as a system that "usually works by subscription, using the Internet as shopping platform. The majority of box-schemes in the United Kingdom are run on a local or regional basis by farmers who deliver weekly boxes to customers' homes or to a local collection point." Additionally, Vidal et al. (2011) highlight as key characteristics their regular delivery, product range, and limited customer choice.

Different from other options of AFN, box-schemes do not necessarily involve face-toface contact. This characteristic is very strong in the case of farmers' markets and is considered a significant step change in the quality of the relationship between buyers and sellers (Cicatiello et al. 2015; Hunt 2007; Spilková, Fendrychová, and Syrovátková 2013; Thilmany 2008). Some researchers say that face-to-face contact is imperative for the establishment of a trustworthy tie (Bos and Owen 2016; Thorsoe and Kjeldsen 2016). Compared to CSA and SPG, they do not demand such strong links between actors (Cembalo, Migliore, and Schifani 2013; Fonte 2013; Hayden and Buck 2012; Lagane 2015). The fact that box-schemes share the usage of boxes with pre-defined content, advance payment and a relationship supposed to last longer (subscriptions), approximates it to CSA and SPG but, for these last ones, this combination is not as central as it is for the companies centered around the box-schemes because, according to their principles, CSAs and SPGs demand higher involvement of consumers.

Considering that its appearance is related to capabilities created from new information technologies, box-schemes could be considered a format of electronic commerce. Traditional retail chains have evolved into digital stores, making all their assortment available online to ease grocery shopping. More recently, retailers who have grown solely in digital world have made the opposite movement, invading the physical stores' environments, like Amazon's acquisition of Wholefoods in 2017. In our case, these box-schemes are operated by much smaller companies, with ways of working based on a limited assortment of organic products, delivery contracts expected to go beyond a unique shopping trip, and choices that are not fully flexible, which means that buyers acquire a set of products defined by sellers. These products are usually in season, and buyers have some flexibility to change some of them or add new ones. Yet, what makes it unique is the combination of imposed conditions (pre-defined boxes) and lower involvement (in reference to the engagement of buyers in production and acquisition processes compared to CSA and SPG). To underscore its relevance, in the UK, such box-schemes were pushing organics sales growth by increasing sales two to three times the market average and represented 11\% of the total organic sales in 2015 (Organic research center 2016; Soil Association 2014). These initiatives would simply be an electronic commerce format if they were not breaking the freedom of consumers to choose what they want in favor of a standard box. Having said that, I defend the box-schemes as an AFN itself because of alternative patterns that differentiate them from 
conventional retailers as well as from most similar AFNs. Thus, box-schemes are the commercialization system in which customers buy a pre-defined basket of fresh food without any tactile experience, accepting assortment, delivery, and payment conditions imposed by suppliers that also define a certain level of customization.

Considering its potential as alternative for small producers excluded from the conventional system, what are the alternative practices and conditions in which producers and consumers establish box-schemes? This article intends to understand the practices and conditions connecting suppliers and customers and its capacity to involve the latest in rural challenges. The hypotheses initially conceived based on the studies about other AFN and the knowledge of theoretical framework presented above about trade relationships are:

1) Information technology is essential to promoting and creating customer confidence under conditions in which society is evolving into new relationship forms, and presential contacts are being replaced by new possibilities of connection.

2) Connections goes beyond commercial contracts to reach moments and circumstances that indicate social bonds, interdependences, and relationships of care that take place to demonstrate a sense of friendship; therefore, customers become more sensitive to agricultural challenges and how their consumption will impact farmers.

Qualitative methods were deployed to analyze three cases of box-schemes in Brazil. The results are presented in sequence to highlight the possibility of AFN, like boxschemes, to strengthen urban-rural ties and build responsible consumption.

\section{Retail as an opportunity for human interaction}

The origin of an AFN may vary a lot; it can be born simply from a market failure such as supply issues ( $\mathrm{Si}$ et al. 2015) or driven by complex necessities of new political stewardship among citizens (Lagane 2015), for example. Times of produce shortage have seen the rise of self-provisioning structures in both socialist and capitalist worlds (Mincyte 2012; Naylor 2012). More recent quality issues in meat supply are supposed to have triggered the search of organic food by many consumers, from the UK to China (Si et al. 2015; Wang et al. 2015). Other cases demonstrate that AFN are linked to an upscale form of consumption and would be linked to status demonstration by part of the population (Jehlička and Smith 2011; Kato and McKinney 2015; Smith and Jehlička 2013; Vittersø and Tangeland 2015). At the same time, Cicatiello et al. (2015) associate the participation in AFN to rational needs (including personal values), hedonism, and sociability. According to them, embeddedness is an important lever for AFN development even when main organizational drivers are egoistic reasons like health and quality food supply. This is because trustworthy relationships are needed to guarantee food quality and environmental concerns are addressed (Baldi et al. 2019). The possibility of the social network influence in the choice was found by Migliore et al. (2014) studying SPGs in Italy, where a strong correlation links these groups to the Slow Food movement. Trustworthy information and the belief that an individual choice can make a difference in a specific cause may be linked to the potential importance of an embedded purchase act (Vermeir and Verbeke 2006). 
From the Economic Sociology perspective, trade relationship is a rich area to observe economic agency (Glucksmann 2000). Polanyi (2012) proposed that the economic integration could happen in three different ways: commerce, redistribution, and reciprocity. Commerce is currently the main form, broadly known by everyone and defined by the exchange of goods and services. Reciprocity and redistribution are ancient forms of integration, conceived before currency creation and still a strong format of economic linkage in archaic communities. Reciprocity refers to the act of benefiting others driven by the expectation of being benefited by others in the future (Mauss 2007; Sabourin 2011, 2012) and is linked to the logic of gift. Sykes (2005:1) claims that "the gift can seem a small thing, but the habit of giving and receiving gifts resonates through human lives because the gift is more than the material object. It establishes or confirms a relationship between people." Gift may simply be an uninterested donation while reciprocity, for some scholars is an interested act (Hénaff 2009). Regardless of its dimension of economic interest, reciprocity is an acknowledgement of the relationship that may take place in different scales, including on the individual level (Hénaff 2009). Sabourin (2011) states that reciprocity can trigger values and friendship, ultimately resulting in justice. Thus, links established under reciprocity values demand development of trust, either between actors or an actor and its social network, aspects closely related to the social embeddedness of the economic act (Granovetter 1985) that determines not merely commercial relationships but loyalty, thankfulness, and identity (Courlet and Pecqueur 1992). In conventional retail networks, a reciprocity integration is not supposed to be relevant, as clients are not usually establishing human ties when they go to the store, grab what they need, and return home, barely talking to anyone (Cicatiello et al. 2015). In AFN, interactions are many times needed, and they will depend on what kind of AFN we are considering (Hinrichs 2000).

Polanyi (2012) also discusses the possibility of integration through redistribution. It is also observed in ancient communities by the habit of centralizing part of or the whole harvest and hunting on the community member accountable for redistributing them across the community and avoiding inequality. This practice guarantees every member will be provided for, regardless of health, age, or any other special condition that could prevent any member from being equally nourished. The contemporary world sees a strong prevalence of commerce over the two other integration formats, but it does not mean they do not exist or, more important, that they do not co-exist when consumers choose what and how to purchase (Sabourin 2011). Considering the growing influence of neo-liberal economic thinking and the decline of the welfare state, former structures of redistribution could be occupied by mechanisms born from civil societies as social innovations (Haddock 2013; Moulaert, MacCallum, and Hillier 2013; Tremblay, Fontan, and Klein 2009). Organic food consumers are frequently associated with trade formats that are considered more fair (Hemmerling, Hamm, and Spiller 2015), and these consumers are even willing to pay premium prices when profits are to promote equity across the supply chain; this behavior is even stronger among those who spends more on organics (Briggeman and Lusk 2011).

For Glucksmann (2000), retail represents a link that is not well observed in the often studied dyad of production-consumption. This moment is so important that companies focused on retailing are now giant organizations, more influential than many industries and even countries, from a macroeconomic standpoint, globally (Reardon and Timmer 
2012). This environment has changed quickly driven by different facts, among which we find globalization trends, information technology, and economies of scale.

Observing this fast-evolving society, Glucksmann (2000) still highlights a transformation of the role of women over the last century, as they search for gender equality. From a retailer perspective, the habit of shopping starts to be redefined when women do not accept it as a non-remunerable responsibility. The change fosters the search for more efficient methods for household supplying, embracing not only the reassignment of the task but also new channels, technologies, choices, etc. Another aspect impacted by the changing role of women is the responsibility over the family's food and nutrition, something that needs to be delegated or reformulated. Nonetheless, women continue to be the primary person responsible for food provisioning in AFNs, combining new demands with adapted formats to handle everything (Hashem et al. 2018; Som Castellano 2015). In other words, the search for trade conditions that are fairer may coincide with a transformation of purchase habits when women and men revisit their roles regarding non-remunerated tasks related to the family support. In search of new retail formats, AFN can be identified as more trustworthy due to its supposed stronger social embeddedness (Cicatiello et al. 2015; Hinrichs 2000; Hunt 2007; Lass et al. 2005; Thilmany 2008).

New retail formats are also a result of the convergence of emerging needs related to the changing of women's roles and new technology possibilities. Considering digital formats, Przepiorka (2014) considers purchase acts either as only transactional or as able to establish relationships, and that is linked to the capacity of verifying the quality of the good under negotiation. Occasional transactions involving things whose quality is verifiable present a low risk event. In case it is not possible to verify the quality, the risk increases, and the influence of prestige will be important to build trust. Here is where Internet reputation systems play an important role to develop confidence. On the other side, regular transactions will foster closer relationship inherently and it is supposed to last longer, depending on the establishment of trust created out of the satisfaction of both sellers and buyers. In summary, trust in occasional transactions comes out of prestige but trust in regular transaction depends on relationship (Przepiorka 2014). In these cases, given the intrinsic variability of agricultural products, it depends on the regular verification of its quality and the trust on the supplier, when only the long-term usage will build a platform to repair possible failures. This is a third aspect brought to the possibilities influencing the emergence of new trade formats that are created based on new possibilities for communication and meaning exchange (Sykes 2005).

The fact that channel and consumption could be used as political tools raises again the possibility of connections beyond the commercial exchange. Wilkinson (2010) proposes that AFN driven by political reasons are mainly ignited by social movement leaders, politicized citizens, and the public sector. For Dubuisson-Quelier, Lamine, and Le Velly (2011), the members of consumption social movements could be split into engaged, recruited, and opportunists. Considering only individual manifestations, we disregard the public procurement and the other five types that may be valuable in the construction of mass consumption through AFN. Yet, engaged and recruited customers could be taken as social leaders and politicized citizens, while opportunists would remain as a group of adopters, not really moved by the values that fuel such movements. In the case of Stevenson et al. (2007), a different role is attributed to different 
movements. According to their demands and results, they would be warriors, builders, or weavers. From this standpoint, AFNs could be taken as builders once they come up with solutions to the warriors' demands. Nonetheless, it is interesting to note that Baldi et al. (2019) found that most engaged consumers in SPG in Milan (Italy) were egoistic centered while a large group of less involved consumers were followers with altruistic objectives, contradicting the idea of social engaged leadership in AFNs.

When traced back to the organic agricultural foundations and evolution, we find the roots of a social movement in favor of an agriculture less dependent on external and industrialized inputs, against the green revolution that has massified and intensified productions to maximize output (Luttikholt 2007). Bringing it to the bifurcation moment we mentioned before, pioneer activists that preserved low input agricultural methods in organic production may have evolved into activists that refused to participate in (or were excluded from) the conventional system to kick-off new retail formats. Both followed by consumers supporting sustainability ideas may see their system growing up to a point that other consumers start to join the movement without necessarily being engaged with the cause, but motivated by externalities such as convenience or quality.

Differences in the way AFNs are created and grown may end up in different impacts. Thus, farmers' market may be stronger in creating producer-consumer links while direct sales are more efficient in terms of demand stability and economic return (Mastronardi et al. 2019). In the end, box-schemes are an AFN that is closer to regular commercial practices but may keep a certain alterity that fits consumers' need to contribute towards fairer and more sustainable practices in food trade. They may reinforce economic integration beyond trade practices and enable information flow to consumers that previously were disconnected from producers and vice-versa.

\section{Methodology}

In order to explore the possibilities around this emerging channel format, a multiple cases study was conducted based on telephone interviews of customers, face-to-face interviews of owners and employees, websites' content, and the sales data of the companies in each selected case (Creswell 2007; Yin 2014). Its benefit is to provide different perspectives in situations in which experiments are not appropriate. As the object of the inquiry was the relationship, it was essential to hear owners, employees, and customers of box-schemes to map what was exchanged in the contacts and how (Fuhse and Mützel 2011). As its first and main relationship is commercial, the exchange of products and money is natural and evident, but the non-conventional way of buying fresh products may go beyond the pragmatic commercial approach to strengthen trust and generate value, that is why the search of non-commercial exchanges is needed.

The study took place in the city of São Paulo. The selection of the initiatives was based on the universe defined by two sources. First, an initial group of companies was formed by the result from a web search using Google as engine. Keywords used were "organic food delivery sao paulo" (entrega alimento organico sao paulo). A second group of companies were identified by questioning the companies of the first phase whether they know other companies working in box-scheme (snowball approach). In total, the city counted on 18 companies, most of which had online sites for order acquisition, while only one was working exclusively through Facebook ${ }^{\circ}$, and another one was present only offline. All but one were contacted and five of them were interested in 
participating; however, only three initiatives were used given their capacity to provide structured sales data. Although the sampling method may not have covered the real universe of enterprises working with box-schemes, the small number of new companies operating without any virtual element, as identified after the snowball approach, indicates a high level of exhaustiveness. Following the recommendations of Yin (2014), the cases were chosen as a proxy to what could be going on in similar groups.

Once companies were identified, the databases with isolated transactions containing sales from November, 2016, to March, 2017, were used to understand the purchase acts, purchase patterns of each customer, and overall sales characteristics of each company that allowed the linkage between actors' discourse and habits. Only one specific case could also contribute to the database of messages linked to the purchase occasion, which allows us to understand the content of the communication from customers to companies. Considering their sales data, customers were segmented into three groups: (1) regular customers that bought every 15 days or more often; (2) occasional customers that bought less frequently; and (3) trialists that bought only once.

Based on this segmentation, a purposive sampling (Tongco 2007) was conducted to represent each type of customer. An objective of 10 interviews per company was defined, considering a balance across groups of customers. The recruitment first followed self-selection (Jupp 2006; Lund Research 2012) triggered by the same invitation to participate that was sent through e-mail by each company to the whole customer database. After self-selection was completed, we conducted an active recruitment through phone to guarantee that all customers' segments defined above were represented (regular, occasional, and trialists). This process was a request from the companies to minimize disturbance among clients. Altogether, the three companies have sold to 1782 households in the period analyzed, out of them, 31 interviews were conducted lasting from 15 to $30 \mathrm{~min}$ (18 were voluntary and 13 were actively recruited). The semi-structured interview counted on 10 open-ended questions split into three areas: customer characterization and network; reasons to choose organic and home delivery services; satisfaction and improvement areas for home delivery services. It was impossible to record the interviews; therefore, the content was registered in a field diary.

All interviews with company owners and employees were face-to-face. In this case, the universe comprised 52 people and we interviewed 10 among them. The selection was purposive to include only those who were responsible either for the company management or for the contact with clients. This work happened between January and April 2017. These interviews lasted from 1 to $2.5 \mathrm{~h}$ and involved exploratory questions split into four areas: employee identification, values and mission of the company, daily routine, and experiences from the contact with clients. Whenever possible, interviews were recorded and transcribed. Finally, a confidentiality agreement containing the research conditions were signed off by the person responsible for each of the three companies. Figure 1 summarizes the process of recruitment.

Regarding its internal validation, the most important risk identified is the selfselection recruitment (Lund Research 2012) or volunteer sampling (Jupp 2006) that may represent a bias that would imply in misleading results. The cross-reference between information provided by employees and consumers is supposed to attenuate the interferences. 


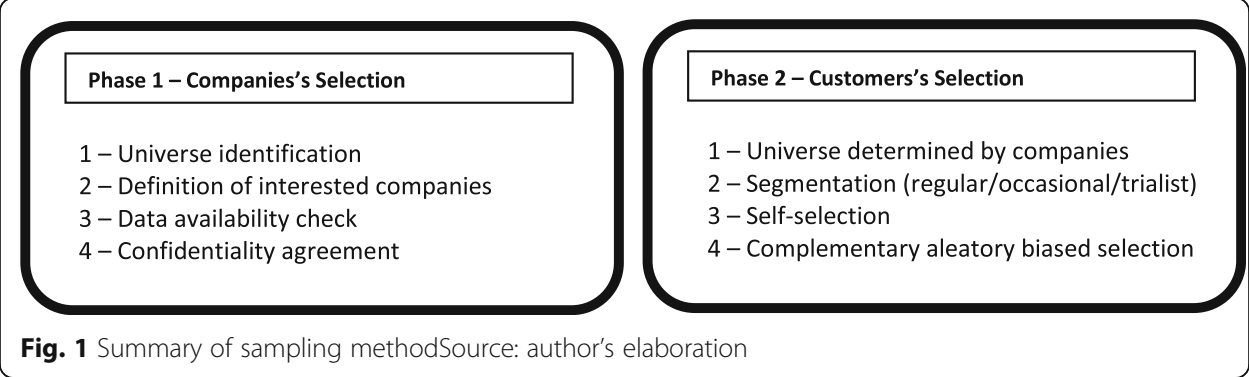

The responses provided by the interviews were complemented by the information sourced from companies' websites. They were used to characterize the initiatives, according to what was proposed by Forssell and Lankoski (2015) to classify their different types of AFNs based on three dimensions: history, central characteristics, and results. It may also represent an approach to analyze its likelihood to be a pre-figurative format of sustainable consumption (Fonte 2013). The history of a given initiative will confirm their social engagement; nevertheless, its evolution will depend on the new customers that may be attracted by its social objectives, but could also come due to prices, availability, and quality, the so-called opportunists. The analysis of the content found in the websites was made with $\mathrm{NVivo}^{\circ}$ software support that imported the texts preserving its integrality. Given the lack of uniformity to capture the interviews with owners, employees, and customers, the same method could not be applied to analyze the content of the interviews. Such analysis was made following principles inspired by narrative methods as context and emergent themes (Creswell 2007).

\section{Results and discussion}

Results were split into four parts that start by a structural understanding of the networks in question. The second and third parts will be focused on the content of the customers and employees interviews, respectively. Eventually, customers' feedback was included into the employees' section to support their answers and provide a better understanding. A final discussion is presented in the sequence to summarize the ideas and interpretation of the results.

\section{Description of selected cases and purchase patterns}

An overview of each case is available in Table 1. They present a very diverse set of characteristics, mixing short and long-term experiences, different sizes, and reasons to be started. On the other hand, they share very similar market practices, whose main difference relies on the flexibility to alter the content of the weekly basket. We find another nuance when we look at the characteristics of the results highlighted by each of them when they emphasize price (case 2) or a social engagement (case 1).

As an indicative of the strength of their commercial relationship, Table 2 shows the distribution of customers' profile according to the frequency as well as their importance to the company revenue, which illustrates companies' dependency on frequent buyers and on the generation of new customers. This segmentation is proposed to allow the comparison between consumers with different levels of engagement with box-schemes as, regarding organic food, engaged consumers shows stronger altruistic behavior and 
Table 1 Characterization of the cases

\begin{tabular}{|c|c|c|c|}
\hline & Case 1 & Case 2 & Case 3 \\
\hline Foundation & 1981 & 1995 & 2016 \\
\hline $\begin{array}{l}\text { Number of } \\
\text { employees }\end{array}$ & 41 (including production) & 3 & 8 \\
\hline $\begin{array}{l}\text { Number of } \\
\text { customers }\end{array}$ & 1261 & 406 & 115 \\
\hline $\begin{array}{l}\text { Average } \\
\text { weekly } \\
\text { deliveries }\end{array}$ & 300 & 70 & 35 \\
\hline $\begin{array}{l}\text { Historical } \\
\text { characteristics }\end{array}$ & $\begin{array}{l}\text { Its founder is an agronomist } \\
\text { who has fought for organic } \\
\text { production and better } \\
\text { conditions of rural life. The } \\
\text { company website offers } \\
\text { details about its } \\
\text { development. }\end{array}$ & $\begin{array}{l}\text { The initiative was created due } \\
\text { to an opportunity identified by } \\
\text { its founder. He used to work } \\
\text { in a large department store } \\
\text { chain and realized an } \\
\text { important price gap between } \\
\text { organic and conventional } \\
\text { products in the main grocery } \\
\text { chain. }\end{array}$ & $\begin{array}{l}\text { Family owned business that } \\
\text { has recently started. Yet, its } \\
\text { background shows a strong } \\
\text { interest for the } \\
\text { environmental and food } \\
\text { causes. Two partners are } \\
\text { environmental engineers, } \\
\text { and the third one studied } \\
\text { gastronomy. }\end{array}$ \\
\hline $\begin{array}{l}\text { Central } \\
\text { characteristics }\end{array}$ & $\begin{array}{l}\text { Orders should be made by } \\
\text { Sunday night to be delivered } \\
\text { Wednesday/Thursday. } \\
\text { Payments made in advance. } \\
\text { Standard baskets were } \\
\text { incentivized but full } \\
\text { customization is accepted. } \\
\text { Only organics produced in } \\
\text { different farms, including } \\
\text { self-production. }\end{array}$ & $\begin{array}{l}\text { Orders should be made by } \\
\text { Sunday night or Tuesday night } \\
\text { to be delivered on Wednesday } \\
\text { or Friday, respectively. } \\
\text { Payments made in advance. } \\
\text { Two sizes of basket were } \\
\text { offered with a long list of } \\
\text { optional items, many of which } \\
\text { industrialized. } \\
\text { Customers could replace some } \\
\text { items. } \\
\text { Only organics bought from a } \\
\text { central partner and } \\
\text { complemented } \\
\text { by spot suppliers. }\end{array}$ & $\begin{array}{l}\text { Deadline to place orders is } \\
\text { Sunday night to be delivered } \\
\text { on Wednesday and Thursday. } \\
\text { Payments made in advance. } \\
\text { Two sizes of baskets offered } \\
\text { with few customization } \\
\text { possibilities. }\end{array}$ \\
\hline $\begin{array}{l}\text { Results } \\
\text { characteristics }\end{array}$ & $\begin{array}{l}\text { Health, socio-environmental } \\
\text { sustainability, rural } \\
\text { development }\end{array}$ & $\begin{array}{l}\text { Health, } \\
\text { pesticides free } \\
\text { lower prices }\end{array}$ & $\begin{array}{l}\text { Health, socio-environmental sus- } \\
\text { tainability, rural development } \\
\text { Fair prices }\end{array}$ \\
\hline Interviews & $\begin{array}{l}\text { Owner } \\
\text { Administrator } \\
4 \text { customer service assistants } \\
11 \text { customers }\end{array}$ & $\begin{array}{l}\text { Owner } \\
13 \text { customers }\end{array}$ & $\begin{array}{l}3 \text { partners } \\
7 \text { customers }\end{array}$ \\
\hline
\end{tabular}

are less sensitive to prices (Briggeman and Lusk 2011; Hemmerling et al. 2015). In addition, Table 3 provides a relative expenditure index obtained by dividing the average spending of each segment by the overall average spending, considered in each delivery occasion. From the customers' point-of-view, it is interesting to highlight the lower value per transaction among occasional customers and the tendency to spend more associated with a higher frequency of purchase. Other studies indicate stronger

Table 2 Distribution of customer profiles by case and their importance to the total revenue

\begin{tabular}{|c|c|c|c|c|c|c|}
\hline \multirow{2}{*}{$\begin{array}{l}\text { Customer } \\
\text { segment }\end{array}$} & \multicolumn{2}{|l|}{ Case 1} & \multicolumn{2}{|l|}{ Case 2} & \multicolumn{2}{|l|}{ Case 3} \\
\hline & Revenue imp. & $\%$ of customers & Revenue imp. & $\%$ of customers & Revenue imp. & $\%$ of customers \\
\hline Trialist & $5 \%$ & $34 \%$ & $11 \%$ & $47 \%$ & $10 \%$ & $37 \%$ \\
\hline Occasional & $29 \%$ & $40 \%$ & $34 \%$ & $35 \%$ & $20 \%$ & $24 \%$ \\
\hline Regular & $66 \%$ & $26 \%$ & $55 \%$ & $18 \%$ & $70 \%$ & $39 \%$ \\
\hline
\end{tabular}

Legend: Regular-bought once or more every 15 days, Occasional-bought less often but more than once in the period, Trialist-bought only once

Source: Author's elaboration based on sales data from November 2016 to March 2017 
Table 3 Average spending per shopping transaction index

\begin{tabular}{llll}
\hline Customer segment & Case 1 & Case 2 & Case 3 \\
\hline Trialist & $93 \%$ & $95 \%$ & $98 \%$ \\
Occasional & $95 \%$ & $103 \%$ & $85 \%$ \\
Regular & $117 \%$ & $107 \%$ & $111 \%$ \\
\hline
\end{tabular}

Description: Customer segment average spending divided by overall customer average spending based on delivery occasion based on sales data from November 2016 to March 2017

Source: Author's elaboration

interaction and, therefore, social embeddedness as associated with higher spendings and credibility (Bos and Owen 2016; Cicatiello et al. 2015; Hunt 2007). This may be a singular characteristic among box-schemes' consumers as other AFNs, like SPG, indicates most engaged consumers associated with egoistic concerns (Baldi et al. 2019). In this case, Internet-based sales limits interaction but does not mean connections are not made in alternative ways, what is also dependent on cultural factors and practices that vary across geographies (Brown et al. 2009; Granovetter 1985; Hashem et al. 2018; Hemmerling et al. 2015). This suggests that in-person contacts are not mandatory as proposed by Bos and Owen (2016) and Thorsoe and Kjeldsen (2016).

In case 2, we were able to access a database with the content of messages exchanged between seller and customers individually. This data is summarized in five categories introduced in Table 4. It points out that regular customers establish clearer expectations, expressed by the higher incidence of regular customers in the product quality comments. The feedback received from customers is also important in farmers' market to adjust offer (Cicatiello et al. 2015; Hunt 2007; Lass et al. 2005). On the other hand, trialists and occasional customers are more concerned in making sure their payment was received, and they know where to deliver the basket (occasional customers were responsible for half of the payment confirmation comments and $64 \%$ of the addresses confirmations). The difference regarding the content of communication indicates the stronger concern about the financial transaction among less engaged customers, coherent with previous findings (Hashem et al. 2018; Hemmerling et al. 2015).

This case raises the possibility of an effective coordination to be achieved with the usage of proper technology. Of course, this is not going to develop in the same way in every single social group, as pointed out by Hemmerling et al. (2015). The emergence of new tools and the gradual adoption of innovations mean that online communication

Table 4 Comments classification as percentage of total comments by type

\begin{tabular}{lllll}
\hline Comment type & Trialists & Occasional consumers & Regular consumers & Total comments \\
\hline Payment confirmation & $21 \%$ & $50 \%$ & $29 \%$ & 56 \\
Delivery details & $39 \%$ & $47 \%$ & $13 \%$ & 38 \\
Product quality & $7 \%$ & $41 \%$ & $52 \%$ & 29 \\
Address confirmation & $23 \%$ & $64 \%$ & $14 \%$ & 22 \\
Payment adjustments & $23 \%$ & $31 \%$ & $46 \%$ & 13 \\
Others & $13 \%$ & $13 \%$ & $75 \%$ & 8 \\
Total comments & $23 \%$ & $46 \%$ & $31 \%$ & 166 \\
Number of deliveries & $13 \%$ & $35 \%$ & $51 \%$ & 1440 \\
\hline
\end{tabular}

Source: Author's elaboration 
using different tools (videos, chats, e-mails, voice message, etc.) has the potential to create bonds that initially were only possible in-person.

The other two cases were not able to share the same information in a way that we could empirically and quantitatively verify it; on the other hand, we will be able to capture similar patterns from the content of the interviews.

\section{The customer standpoint}

To introduce the perspective from customers, we start with their choice for a boxscheme. The way customers often found the company was through an Internet search, although they have not mentioned a more in-depth survey to analyze its prestige. As initial contact, it is not what it is expected from the analysis of Przepiorka (2014) and revealed a certain risk taken by these customers. In the same way, considering that the choice of the company could have been influenced by its reputation in their social network, most interviewees claimed not to know others who buy organics from the same supplier. The ones who did, referred to people they were not very close to (distant neighbors, for instance), explained that they knew of it because they could see the delivery. Broadening the question from the same supplier to other box-schemes, we find that this alternative could have been introduced by someone else who faced similar issues in the past, but they are not aware if the person buys from box-scheme and whether they count on the same supplier. The only exception is found in case 3 , in which different interviewees claimed to have received a recommendation from a professional and have also recommended it to others. When asking about possible affiliations, we notice that they are nutritionists associated to the Functional Nutrition Association. A possible reason for finding the influence of the social network only in this case is the size of the company, who counts only on 115 customers; this is $28 \%$ of the number of customers of the company in case 2 and $9 \%$ in case 1. In comparison to SPG and CSA, the absence of more social links between network members also indicates that consumers of box-schemes are not active influencers of their networks nor engaged in the expansion of this format (Lagane 2015; Migliore et al. 2014). This consideration raises the possibility of box-schemes being sustained by social networks in initial phases. Later on, the network grows according to innovation diffusion patterns (Diederen et al. 2003) and early adopters may not be part of the same network formed by recent customers.

The reasons to switch from conventional channels to box-schemes are usually related to a market failure, like availability, too high prices or poor quality in conventional stores, reinforcing the findings of other AFN and organic food studies (Cicatiello et al. 2015; Hemmerling et al. 2015; Hunt 2007; Si et al. 2015; Spilková et al. 2013). An additional relevant observation is that all interviewees but one were women, which brings up the possibility raised by Glucksmann (2000) about changes that are initially driven by the modern role of women in society, forcing other changes. Nevertheless, it highlights that men are not yet assuming this responsibility that seems to remain under women's scope of action. Frequently, interviewees mentioned their profession and occupation, what includes them in the group of women that have accumulated functions. Thus, the lack of time is probably a factor that makes them search for alternative forms of purchase when formats that deliver expected assortment and quality are conflicting with available time and willingness to go to physical stores. On the one hand, this 
reinforce the role of women in food provisioning found also in the USA (Som Castellano 2015) and England (Hashem et al. 2018) that indicates an uneven distribution of home tasks gender wise. But, on the other hand, we note that, in those countries, socioenvironmental concerns were driving customers' choice while in São Paulo customers were mainly driven by hedonistic reasons restricted to the circumstances. This is to say that subscribing to box-schemes was the only way to perform their functions as professionals and household providers driven by hedonistic reasons instead of socio-environmental concerns. The apparent difference may be explained by the time customers have participated in such schemes and the efforts of these schemes to create awareness about agricultural challenges (Hashem et al. 2018). In the comparison of the three cases, we can also find more engaged customers in the initiative that has worked on this front for longer.

Additionally, the responsibility for food provisioning makes customers usually report their frustration for not being able to choose their products after a close look. The sensorial experience is part of the conventional procurement of fresh produce, and this makes clear the trust built between them and the company's customer service team. Such frustration is compensated by the convenience, quality, and provided assortment they could not find elsewhere.

This is expressed in the comments below:

"...home delivery is not good because you cannot see the products before. Whenever it is spoiled or it is not good, they reimburse me. Even though I like to see, touch, choose... but I let it go!" - customer

"... in the grocery shop you see, choose, realize the quantity. It is more than imagined. Sometimes I cannot realize through the list. In the grocery shop it is more tangible."-customer

"As we adapt ourselves to everything, we became more tolerant. The product does not always come as we imagined. But returning is a hard task."-customer

However, establishing a personal relationship, usually counting on phone calls or messages that specify expectations, depends on the technology enhancements that result in cheaper phone calls and creates new media that allow not only voice transmission but also almost instant communication of pictures and videos (Kumar 2004; Thorsoe and Kjeldsen 2016).

Customers who have not bought more than once indicate that something failed to convince at least part of them to keep buying. In their interviews, we perceive a less tolerant behavior, they are not satisfied either with the quality or with the price; in other words, they do not think it is worth it. Additionally, their interviews reveal they have other possibilities of source, and the box-scheme is not their favorite option. They do not buy more often because they also use farmers' market and conventional grocery shops, looking for quality and price, this is to say they do not trust suppliers and need to verify the quality of the goods (Przepiorka 2014). An interesting testimonial presented a certain incoherence when the customer said to be frustrated because prices were not fair, but she was expecting even more as service. Considering her occupation 
and background, in regular conditions, income should not represent a real barrier nor make them occasional buyers, but the unmet needs and lack of trust may be behind the decision to stop buying or to look for another source. Conversely, it is intriguing to notice that regular customers report occasions when they were not very satisfied with the products but still accepted them. Hayden and Buck (2012) found a similar difference in terms of tolerance among CSA participants.

Financially wise, case 2 revealed frequent mentions of prices; however, it was not the most important aspect of their choice that relied on the quality of products and service provided. Although some customers mentioned socio-environmental concerns, their comments did not show signals that their choice for box-schemes is driven by it. The next example shows comments from the same customer in favor of small farmers, but dissatisfied with prices that she expected to be lower compared to the conventional chain: "I like $\mathrm{MST}^{1}$ products. I went to the Água Branca farmers' market and got to know that the MST will have a place to distribute their products." A little later, she places her concern with price: "Sometimes it is more expensive to buy on-line than going to the grocery shop." This could be taken as a lack of involvement, once she is also expecting lower prices linked to the channel and not necessarily to rural conditions.

In this case, when answers from regular and occasional clients are compared, we find that the latest are switching among different suppliers according to more attractive prices. This could pose a chicken-and-egg problem between customers looking for price and the supplier that emphasizes such benefit, the exact paradigm usually found in the conventional retail and coherent with neoclassical economics. But the comparison to case 1 brings the possibility to understand that case 2 is not economically integrated by social bonds as the first one. It also reinforces that customers may only accept to pay premium prices when this extra profit will go to smaller farms (Briggeman and Lusk 2011).

Another interesting data point to look at is the importance of occasional customers for case 2 revenue (Table 2); it is the highest one, while it is the only case where occasional customers' spending is a little higher than the overall average for the company (Table 3). This may be related to this opportunistic behavior and its relation to lower interest in socio-environmental concerns. As they are less engaged, these occasional buyers spend more on single deliveries but, in the long run, they may spend less in organic produce (Briggeman and Lusk 2011; Hemmerling et al. 2015; Hunt 2007).

When looking at case 3, regular customers considered it a good value, while trialists said it was not worth it. It is interesting to notice that they always made the price comment in reference to a conventional retailer. In the case prices were considered good, the used reference was a chain known for practicing very high prices. In the end, the cases 2 and 3 show that price still has an important role, but may be compensated when a history of engagement convinces customers to pay more (Hashem et al. 2018; Hemmerling et al. 2015). In the case of farmers' market (Hunt 2007), price played a secondary role, perhaps similar to that of case 1 , but in cases 2 and 3, price seems to have a higher relevance. A possible reason may be the lack of arguments to sustain a

\footnotetext{
${ }^{1}$ Movimento dos Sem Terra is an important social movement that defends small producers without land against large unproductive lands and farmers.
} 
social development discourse in case 2 and the short time history in the case 3, which leads us to consider that the content and consistency of the message from box-schemes to consumers across time have a key role in moving the needle from price to quality in box-schemes (Hashem et al. 2018; Vermeir and Verbeke 2006).

Across clients of case 1, we verify the strongest concern with social justice and environmental sustainability up to the point that they think this is an opportunity to contribute to rural ways-of-living as small farmers are being better remunerated. This involvement seems to be the result of efforts to educate consumers through two mechanisms. First their webpage, where the historical content of the pioneer makes clear its engagement to improve life conditions in his community. Second, a regular leaflet that accompanies the baskets. In both media, customers are also invited to visit the main farm, taste their products, and engage in any of the programs to better understand how it works, therefore, opening opportunities to strengthen links is crucial (Bos and Owen 2016; Hayden and Buck 2012; Thorsoe and Kjeldsen 2016). Only one customer declared to have paid the visit and demonstrated a profound engagement with the producer, but the engagement can be verified in other customers as well, as in this comment:

"Knowing that there is a family that does not live in São Paulo and does not need to move here. It goes beyond commercial stuff. They will not have scale to come to Pão de Açúcar (main grocery chain). I'm helping! I'd like to do more, but, in times of crisis, I cannot."-customer

While cases 1 and 3 present socio-environmental concerns, we see different levels of awareness from customers. In case 3, customers' understanding of rural conditions and the effort of small farmers to sustain the rural environment is not present in any interview. We could assume that their customers were not educated yet about these topics given a more recent relationship. Moreover, regarding case 3 , we have already mentioned a stronger influence of the social network in which it is embedded and a less important influence from the Internet search in the establishment of the seller-customer link. This finding may come from a possible bias of the sample or it may be related to the smaller size of the company. Although, case 3 illustrates a situation in which the online communication is less relevant to establish initial customers, making its historical characteristics and altruistic results less important in the customers' choice. The comment that follows represents this kind of social network influence.

"I have many patients that buy there. I laugh a lot because they complain but then they remember that organics are not always beautiful. There is a lack of awareness regarding what organics are. Many find them ugly and they expect it to be always pretty."

From a customer's standpoint, the food procurement through box-scheme is an option initially driven by individual needs but, depending on how the relationship with the supplier develops, this choice evolves into stronger ties that unfold more complex reasons to maintain the engagement with the system. 
The construction of box-schemes by entrepreneurs and workers

We now turn to the perspective of employees and owners of box-schemes' companies. From this standpoint, regular contacts keep engagement up. These may be considered amendments to the distance that, in the past, was so short that customers and suppliers could share a cup of coffee and exchange Christmas gifts. Other forms of AFN, like farmers' market (Cicatiello et al. 2015; Hunt 2007; Spilková et al. 2013) and CSAs (Hayden and Buck 2012; Lass et al. 2005), are able to recover the physical encounter of producers and consumers, but that is not necessarily the case of box-schemes since customers only eventually meet deliverers. On the other hand, possibilities born from technology are what soothes the negative feelings reported by customers (Bos and Owen 2016; Thorsoe and Kjeldsen 2016). All three cases presented a strong importance of the customer service area, managed differently according to the size and innovative practices of each case.

In case 1 , as we find a bigger number of customers, we also find a set of employees dedicated to interacting with them in a customer service department. Thus, its four members, all women from 20 to 32 years old who have been working there for up to 5 years, follow a weekly routine that starts on early Monday, when they verify the order acquisition and product availability. They are also able to check clients' access to the system, which indicates interest to buy. In the sequence, they actively call customers to offer help and clarify questions. Priority is given to those who have accessed the system but soon they approach regular customers whom they have identified as having missed new orders. They consider this active checking an essential part of the business as many customers are used to being called. In the second and third cases, the interviewees have not reported an active behavior, unless they have an issue regarding placed orders, but they also claimed to be always available to clarify and support customers' questions. During one of the interviews, the owner was interrupted by a customer, and a bargaining conversation clearly exemplified the interaction. Such a routine was not found in previous studies regarding AFNs; it seems to be a unique feature of box-schemes that are dependent on less active customers compared to CSA and SPG (Baldi et al. 2019; Hayden and Buck 2012; Lass et al. 2005) and lack the inperson support of farmers' markets (Hunt 2007; Mastronardi et al. 2019; Micheels and Boecker 2017).

Then, entirety of this process is intensely dependent on telephone and computer assistance. While many of us are used to thinking that the information revolution only brings about possibilities related to the Internet devices of individuals, these companies also strongly benefit from the dropping prices of the phone systems, in the sense that electronic media is an alternative for voice communication at very low cost (Kumar 2004). The telephone call enables and offers a demonstration of the importance of the human contact. This leads us to consider that the online environment is important, but the relationship demands something warmer, and the awareness that someone is taking care of customers' needs is essential to support the commercial transaction and replace presential contacts (Bos and Owen 2016; Cicatiello et al. 2015; Thorsoe and Kjeldsen 2016). Considering the possibility of using modern tools to give real-time perspective about their work and products, which is an opportunity to further develop contacts, technology allows less intense contacts while simultaneously increasing their frequency (weekly calls, e-mails, 
home delivery, website), which may ease the adaptation of customers and helps to build reliability.

The following extracts exemplify how important the telephone contact is for them:

“I prefer it because we can influence more... 'our lettuce is pretty this week!' - I say; 'Send me one!' - they answer (typical dialogue over the phone). We also communicate when there is a product launch in the week. Customers ask what is tastier. Over the phone we realize we are shopping on their behalf"-customer service assistant

Enabled by modern technology, we have an indication of the importance of such human contact. Attendants consider themselves as representatives of customers, and they feel like they are the eyes and hands of customers to testify to the quality of the produce. But, according to them, the content of conversations is not only related to purchase, many times it also touches personal matters as illness, conjugal issues, accidents, and so forth. These conversations are crucial to create bonding (Hayden and Buck 2012) and emotional links usually found in frequent interaction due to spatial proximity (Cicatiello et al. 2015). Seemingly, the technology creates a new spatial reference that shortens physical distances and nurtures new networks (Castells 2000; Sykes 2005). Afterwards, they create the possibility to provide feedback about the appearance of products and literally push what is needed as demonstrated before, similar to interactions at farmers' markets (Hunt 2007; Micheels and Boecker 2017). Conscious of their responsibility, they are also honest when something may not reach expectations. According to one attendant, over the phone,"(customers) are warmer, it is nice! There are those that become friends. You call them and before you identify yourself, they compliment you by your name."

Of course, not all customers demand the same level of attention, but, in some cases, the relationship reaches a degree in which these ladies receive customers' gifts to reward their dedication and friendship. Interesting cases were mentioned regarding elderly people and raise the possibility that an emotional vulnerability is ultimately driving such depth of relationship. Another interesting aspect commonly reported is the personalization of contacts as most customers know one of the attendants by the name. Although they may not know whether they are talking to the right person, customers look for establishing this contact as a way to generate accountability. When problems happen, they also demand explanations or help based on this one-to-one relationship.

Testimonials from both customers and the attendants can be found in these passages:

"It is nice not to have intermediaries, although the price is often almost the same. I know it will come fresh. They call me!! [...] Organics must have an emotional health. If the package guy does not work with care... does not choose better, I don't even mean more package because less package is better. But it's worth... in the farmer's market, for instance, they sell in a natural fiber basket. It is the carefulness, what pretty! They find ways..."-customer testimonial. 
"She sends us an Easter egg. She deposits money for us to buy Christmas loaf. So, every holiday is like that. And she has never seen us... only on pictures and then she showed it to everyone as we were close friends."-customer service assistant.

In case 2, although there is not a person fully dedicated to assist customers, the owner acknowledges its importance when he manifests the interest to invest and hire someone to manage phone calls and messages. From his point-of-view, this could help to grow the business as it allows a better customer service. Maybe the lack of resources was compensated by having a better system in place.

The second strong opportunity for the interaction is the delivery service. As posed by the administrator in case 1: "it is the last opportunity we have to fix something wrong and guarantee we will delight our customer." In fact, this reverts in the only physical encounter between the customer and the company (several deliveries do not count even on this moment because the box is delivered in the absence of the customer). Such experience is then related to closer ties as well, as reported by them using examples of courtesy as preparing a small snack for the deliverer. But it only happens when the deliverer is also engaged on pleasing the customer and uses certain autonomy to make the last verification, to point out things that may not be well accepted and even to change products or to give discounts when appropriate.

"Sometimes, customers even offer a cup of coffee to the deliverer to demonstrate the level of the relationship. These deliverers, before leaving the basket, check the quality of the food and advise customers about any issue, including recalculating the total value in case something is not proper"-administrator

The gift is seen by Mauss (2007) as a way to create commitment between givers and receivers. He conceived of the importance of an apparent altruistic act from the observations of archaic societies. These practices would have evolved into modern forms of gifting, as before such commitments were made between social groups, nowadays they are established by individuals (Mauss 2007). Sabourin $(2011,2012)$ considers that these acts are, nevertheless, reversible at any time. This takes us to conclude that they are not mandatory in the maintenance of the commercial relation. Their objective would be to strengthen human values that would inhibit oppressive behaviors (Sabourin 2012). The reconfiguration of values is pointed by Goodman et al. (2012) as present in several AFNs.

In case 3, one of the partners is responsible himself for the deliveries. In this case, he is supposed to accumulate all the functions in direct contact with customers. Although contacts through phone and e-mail are usually managed by another partner, they always claim to be the same person. According to them, this generates further trust as customers think they are always talking to the same person. Again, we find a significant concern with establishing personal relationships with customers. The following extract demonstrates the level of personalization they have achieved:

"Everything is perfect. I'm not sure if they pamper me a lot because I'm a nutritionist! (...) One thing that was bad is the duplication of items. After they implemented the possibility of replacement, it is now perfect. Sometimes I send them a 
message to acknowledge their work and incentivize them. (...) for them, the client is king."-customer

In fact, all manifestation of care may be signals of reciprocity, convenient in these relationships. They occur not only in regard to the person in charge of the delivery, but also involving the phone attendants. Polanyi (2012) asks for being careful and not taking simple manifestation of kindness as reciprocity, but, in these cases, I argue them to be important signals that economic integration is also happening through reciprocity. This also represents an opportunity for customers to develop their sense of belonging, pointed by Warde (1997) as a reason for people to participate in alternative forms of food consumption in contrast to the globalization trend. Although many authors consider reciprocity only those acts that are disinterested, others see it as something inbetween a total altruistic and a total egoistic act given the uncertainty of its return (Hénaff 2009). Reciprocity, as a manifestation of mutuality, establishment of familiar and communality sense, is certainly a mechanism that increases consumers' trust that they are not being jeopardized or deprioritized by producers in light of a natural variability of the quality of produce.

Interviewees gave comments about products that were also given for free. This happens when products are not considered good enough for sales. In two cases, the companies were also producers that sometimes faced issues with product patterns, like a carrot that came out too small. Even in the case the company was not a producer, in some moments it had to buy products considered two small, unripe, too ripe, etc. If they sent such products, they would jeopardize their reliability, but that does not mean they cannot send them without charging for them. When it is the case, two options were mentioned: when they know it is going to ripen and its amount does not represent a significant financial hit, they advise the customer about the conditions of the product and let them decide about it. Other instances, either they have a small quantity or they are not sure if the product is going to ripen properly, they send the product as a gift, making it clear about the conditions and, when products were ordered, they sent them without charges as an attempt of the best they could do, being aware that it was not enough. The gift and the transparency, regardless of its opportunistic character, captivate customers because they avoid creating expectations that will not be reached. In farmers' markets, the transparency is automatic in relation to product quality because customers can verify it by their own, even tasting the products (Cicatiello et al. 2015; Hunt 2007; Si et al. 2015; Spilková et al. 2013). Furthermore, when such expectations exist, the product quality frustration is compensated by the supposed honesty of not charging for it. Although these examples take place around a commercial transaction, they are not part of a contract, neither are they somehow imposed in the relationship what reinforces its reciprocity content because there is no guarantee of return (Mauss 2007; Sabourin 2011).

Altogether, an analogy made by one customer service assistant was very insightful to summarize their relationship: customers count on them to be their eyes to choose the best possible option. This analogy denotes a dependency on each other. If consumers' own eyes cannot see, they need a trustworthy supplier to lead them. The opposite is also true: the company will only succeed if they take their customers to the products they expect. If one cannot reasonably live without the other, they reward each other in 
ways not foreseen by contracts to compensate for faults. Here is where a cup of coffee, an Easter egg, a memory picture, a free product play a complementary role to reinforce the commitment because it is not all about money, things may also contain sentimental values (Mauss 2007; Sykes 2005). We do not find in other AFNs examples of gifts between sellers and consumers, what opens room to consider that these gifts also collaborate to compensate the lack of in-person contacts. The relationship that is primarily virtual and gets concrete on the box-scheme exchange may count on these gifts to be confirmed beyond its commercial side (Sykes 2005).

The historical dimension of these cases (Table 1) and answers from customers regarding the socio-environmental concerns are not so strong in employees' and owners' interviews. In case 3, one of its partners gave the following contribution:

"and then, they (conventional farmers) cannot pay anybody well. They pay themselves well and everyone else earns a minimum wage. (...) This relationship is too capitalist, extremely verticalized. While here, given a less verticalized system, we have less employees but they are more engaged. They participate from the beginning to the end and earn better salaries. We can pay better because each one of us has a broader responsibility too and nobody oversees a single task. This creates a story for the customer. I do not delivery only organic produce, I create a history. (...) These are enigma that we are finding out in the garden and trying to take to them in the city, so that they can understand the complexity to deliver organics at their home."

On the other hand, in case 2, as discussed before, no mention to such concerns is presented in its website, while its owner does not show the same level of engagement with the rural cause either. It is important to notice that this initiative strongly places prices as a key benefit and it is often mentioned by its owner as a differential. Taking into consideration the registers regarding the role of prices in case 2, the possibility of additional forms of economic integration seems to be minimal for this network, which may be also causing the rise of occasional customers compared to cases 1 and 3 . This is because consumers' decision is also oriented by their belief in the fact that their choice will make a difference to solve problems; therefore, a compelling communication is needed to reassure consumers but only the long-term relationship will be able to foster value changes (Vermeir and Verbeke 2006). In case 1, the long-term consistency is reflected in their customers' discourse and has made them willing to pay higher prices if incremental profit will be distributed across the food chain and, mainly, to support small family farms (Briggeman and Lusk 2011). In case 3, although discourse is similar, there was not enough time to influence customers' values. On the other hand, in case 2, the communication is not focused on these altruistic side and thus, it is not remarkable in their customers' mind.

\section{Commerce-reciprocity-redistribution}

Empirical findings presented here provide a good perspective about the relationship established in box-schemes. In general, consumers who are interested in buying organic produce look for box-schemes as a solution that fits their needs for convenience and 
variety. If the provided services and products meet their expectations, consumers become occasional or regular customers of box-schemes depending on their price sensitiveness and access to other channels. Nevertheless, regular customers may have the opportunity to go a step further and get engaged with them because box-schemes can also represent a political tool to support small farmers and environmental preservation as found in CSAs (Hayden and Buck 2012; Lagane 2015; Lass et al. 2005) and aspired by many organic consumers (Hemmerling et al. 2015).

This story does not happen overnight and may take a long time from being a simple commercial exchange to becoming integrated in altruistic dimensions. Furthermore, an extended integration will also depend on available tools and willingness from both sides as well as on the intention from sellers to educate consumers about agricultural challenges (Vermeir and Verbeke 2006).

Thus, the possibility raised by Fonte (2013) regarding the AFNs to be pre-formative forms of responsible consumption may depend on the intention of involved actors to flourish. As put by Stevenson et al. (2007), these initiatives could be considered forms of social movements aiming to propose alternatives that addresses the need to reconnect producers and consumers in more sustainable food systems. Therefore, the opportunity usually emerges from a market failure in terms of availability but, nevertheless, the awareness about the agricultural conditions is only created when producers intentionally communicate it. On the contrary, the emphasis on commerce and competitiveness also fosters hedonistic reactions in customers. This ultimately results in stronger price concerns from both sides, and we even see a higher importance of occasional customers to the revenue. The lack of emphasis on agricultural conditions in the communications made by producers may be the origin of the deviation of consumers' attention even to environment questions instead of social issues, as indicated by SPGs experiences in Italy (Baldi et al. 2019).

In other words, between the commerce and the accountability for redistributing income, there is the need to strengthen social bonds, which are formed through acts of reciprocity. As an illustration, both cases 1 and 2 provide rich examples of small gifts between sellers and buyers and personalization of relationships. Mauss (2007) proposed that not only the act of giving but also the acceptance of the gift turns into a social obligation for both sides. The institutionalization of contracts marginalized the economic integration through reciprocity acts in recent centuries, but social connection depended on it for thousands of years. Such behavior, once hidden for a long time, has now found a new way to come to life due to the possibilities of reconnection provided by the modern technology (Sykes 2005). According to Vermeir and Verbeke (2006), the trust and social connection is also responsible for paving the way to redistribution because customers need to feel their act can effectively change the situation and reach their objectives. AFNs represent an opportunity to reestablish such links because they can revitalize human contact and build trust (Baldi et al. 2019; Briggeman and Lusk 2011; Cicatiello et al. 2015; Goodman et al. 2012; Hunt 2007; Lass et al. 2005; Mastronardi et al. 2015, 2019; Thilmany 2008). Although huge grocery chains could also claim to redistribute and support small farmers, it is very hard to believe that they can reconnect to customers in self-service stores usually based on economic efficiency principles, according to which prices are key to attract and maintain their clients. The same fact may restrict the growth of companies whose history does not present evidences of 
socioenvironmental engagement (Forssell and Lankoski 2015), the initial credentials to attract politicized and engaged consumers (Dubuisson-Quellier et al. 2011; Wilkinson 2010), essential to make them part of a social movements (Stevenson et al. 2007).

\section{Conclusion}

Box-schemes as reported by the cases used in this study is another example of a transformation under way in our society due to the evolution of technology. It is important to highlight that these initiatives belong to the universe of human entrepreneurship that is very complex, and results cannot be taken universally as cultural codes may interfere significantly. Likewise, given the complexity of such subject, it is not expected that these results exhaust the relationship possibilities in box-schemes. For example, one limitation of the study was to have excluded smaller sellers or less structured ones whose data was not organized enough to our purposes. Anyway, collected experiences can contribute to highlight potentialities of such an AFN.

On the other hand, these experiences highlight alternative technologies, like regular phone calls, as important tool to a warmer and closer contact in place of face-to-face contacts. Another important finding was the lack of evidence that the social network was important to endorse companies and generate trial beyond very initial phases. Usually and in older initiatives, customers were taking the risk based on the information found in the web. Altogether, this exemplified the role technology evolution is playing to make this trade format viable.

If the commerce is the first and main level of integration, reciprocity would be the second level, responsible for tightening ties and establishing the long-term integration. The exchange of gifts and dialogues that go beyond a simple transaction illustrates friendship ties. From customers' perspective, these ties may make them forgive possible failures and lack of the tactile experience. As qualitative tools were used to identify the presence of reciprocity, it would be worth continuing the effort to understand this phenomenon in a quantitative way, as well as how this may influence the commercial side of the integration.

However, there is still a third level, more sophisticated, and thus it demands the relationships to be even closer and more trustworthy, being represented by redistribution. Mechanisms of reciprocity and redistribution should then be important to differentiate AFN with the potential to trigger responsible consumption patterns because consumers may not be initially driven by altruistic interests, as exemplified by case 1 . These companies could transform the reality, finding a sustainable way to collect funds of wealth customers in urban areas to redistribute them in rural territories by recreating the lost bridge between the two environments. Without counting on significant external resources, they are only making consumers to see the value of the small farmers' agriculture and their externalities and paying for it. But such payment is not direct and needs a reliable middleman to guarantee that resources are being fairly distributed.

From the possibilities raised in this article, box-schemes and its singular practices can still be an option for smaller farms, apart from CSAs and SPGs, to build more sustainable food networks. As alternative for customers, they can address the demand for closer relationships with more sustainable and reliable sources while not 
demanding the same level of engagement of other AFNs. It was a first attempt to understand how it works, and the investigation into other geographies would help to understand cultural influences on the construction of reciprocity and redistribution mechanisms. I shall dedicate a last important highlight to the importance of tackling quantitative analysis in the field, which could help to associate real impact of these networks with the support to rural development and confirm such redistribution capability.

Abbreviations

AFN: Alternative food networks; CSA: Community supported agriculture; SPG: Solidarity purchase groups

\section{Acknowledgements}

The author acknowledges the three referees for their comments and challenges that made this article much clearer and more impactful. He also thanks Ms. Sarah MacNeil for her kindly contribution to the quality of its language. Finally, he thanks Prof. Eduardo Caldas and Prof. Tatiana Rotondaro for the relevant questions and suggestions regarding the theoretical framework and the discussion of results. Remaining errors remain with the author. Last, but not least, he acknowledges the fundamental contribution of the enterprises and consumers who accepted to provide time and data to enable this analysis.

\section{Author's contributions}

The author read and approved the final manuscript.

Funding

Not applicable

\section{Availability of data and materials}

Full content of interviews is available at http://www.teses.usp.br/teses/disponiveis/106/106132/tde-05092017-085142/ en.php. Sales databases of the involved companies are available upon request to the author

\section{Competing interests}

I declare that I do not have any competing interests regarding the content of the above-mentioned manuscript.

Received: 19 February 2019 Accepted: 30 June 2020

Published online: 16 July 2020

\section{References}

Baldi L, Bertoni D, Migliore G, Peri M (2019) How alternative food networks work in a metropolitan area? an analysis of solidarity purchase groups in northern Italy. Agricultural and Food Economics 7(1):1-21

Blank SC, Thompson GD (2004) Can/should/will a niche become the norm? organic agriculture's short past and long future. Contemporary Economic Policy 22:483-503

Bos E, Owen L (2016) Virtual reconnection: the online spaces of alternative food networks in England. Journal of Rural Studies 45:1-14

Briggeman BC, Lusk JL (2011) Preferences for fairness and equity in the food system. European Review of Agricultural Economics 38(1):1-29

Brinkley C (2017) Visualizing the social and geographical embeddedness of local food systems. Journal of Rural Studies 54(C): 314-325

Brown E, Dury S, Holdsworth M (2009) Motivations of consumers that use local, organic fruit and vegetable box schemes in central England and Southern France. Appetite 53(2):183-188

Castells, Manuel. 2000. The rise of the network society. 2nd ed. Malden, MA: Blackwell Publishers.

Cembalo L, Migliore G, Schifani G (2013) Sustainability and New Models of Consumption: The Solidarity Purchasing Groups in Sicily. Journal of Agricultural and Environmental Ethics 26(1):281-303

Cicatiello C, Pancino B, Pascucci S, Franco S (2015) Relationship patterns in food purchase: observing social interactions in different shopping environments. Journal of Agricultural and Environmental Ethics 28(1):21-42

Courlet, C., and B. Pecqueur. 1992. 'Les systèmes industriels localisés en France : un nouveau modèle de développement'. Pp. 81-102 in Les Régions qui gagnent : districts et réseaux: les nouveaux paradigmes de la géographie économique, edited by G. Benko, A. Lipietz, and A. Amin. Paris: Presses universitaires de France.

Creswell, J. W. 2007. Qualitative Inquiry and Research Design Choosing among Five Approaches. Sage.

Diederen P, Van Meijl H, Wolters A, Bijak K (2003) Innovation adoption in agriculture : innovators, early adopters and laggards. Cahiers d'Economie et de Sociologie Rurales 67:29-50

Dubuisson-Quellier S, Lamine C, Le Velly R (2011) Citizenship and consumption: mobilisation in alternative food systems in France'. SOCIOLOGIA RURALIS 51(3):304-323

Fonte M (2013) Food consumption as social practice: solidarity purchasing groups in Rome, Italy. Journal of Rural Studies 32 : 230-239

Forssell S, Lankoski L (2015) The sustainability promise of alternative food networks: an examination through "alternative" characteristics'. Agriculture and Human Values 32(1):63-75

Fuhse J, Mützel S (2011) Tackling connections, structure, and meaning in networks: quantitative and qualitative methods in sociological network research. Quality \& Quantity 45(5):1067-1089 
Glucksmann M (2000) Retailing: production and consumption's missing relation. Economic Sociology European Electronic Newsletter 1:12-16

Goldberger JR (2011) Conventionalization, civic engagement, and the sustainability of organic agriculture. Journal of Rural Studies 27(3):288-296

Goodman D, Melanie DuPuis E, Goodman MK (2012) Alternative food networks knowledge, practice, and politics. Routledge, Abingdon, Oxon

Granovetter M (1985) Economic action and social structure: the problem of embeddedness. American Journal of Sociology 91(3):481-510

Haddock SV (2013) Introduction: the pillars of social innovation research and practice. In: Moulaert F, MacCallum D, Mehmood A, Hamdouch A (eds) The international handbook on social innovation collective action, social learning and transdisciplinary research. Edward Elgar Pub. Ltd, Cheltenham, pp 427-429

Hashem S, Migliore G, Schifani G, Schimmenti E, Padel S (2018) Motives for buying local, organic food through English box schemes. British Food Journal 120(7):1600-1614

Hayden J, Buck D (2012) Doing community supported agriculture: tactile space, affect and effects of membership. Geoforum 43(2):332-341

Hemmerling S, Hamm U, Spiller A (2015) Consumption behaviour regarding organic food from a marketing perspective-a literature review. Organic Agriculture 5(4):277-313

Hénaff M (2009) Repenser la réciprocité et la reconnaissance: Relecture de l'Essai sur le don de Marcel Mauss. Revista Portuguesa de Filosofia 65:873-886

Hinrichs CC (2000) Embeddedness and local food systems: notes on two types of direct agricultural market. Journal of Rural Studies 16(3):295-303

Hinrichs CC (2003) The practice and politics of food system localization. Journal of Rural Studies 19(1):33-45

Hunt AR (2007) Consumer interactions and influences on farmers' market vendors. Renewable Agriculture and Food Systems 22(1):54-66

IFOAM, INTERNATIONAL FOUNDATION FOR ORGANIC AGRICULTURE MOVEMENTS. 2005. Principles of organic agriculture: preamble. Jehlička P, Smith J (2011) An unsustainable state: contrasting food practices and state policies in the Czech Republic. Geoforum 42(3):362-372

Jupp, Victor. 2006. Volunteer sampling. The SAGE Dictionary of Social Research Methods.

Kato Y, McKinney $L$ (2015) Bringing food desert residents to an alternative food market: a semi-experimental study of impediments to food access. Agriculture and Human Values 32(2):215-227

Kumar S (2004) 'Mobile Communications: Global Trends in the 21st Century'. Int. J. Mobile Communication 2:67-86

Lagane J (2015) When Students Run AMAPs: towards a French model of CSA. Agriculture and Human Values 32(1):133-141

Lass, Daniel, Nathalie Lavoie, and T. Fetter. 2005. Market power in direct marketing of fresh produce: community supported agriculture farms. IDEAS Working Paper Series from RePEC.

Luttikholt LWM (2007) Principles of organic agriculture as formulated by the International Federation of Organic Agriculture Movements'. NJAS 54:347-360

Mastronardi L, Marino D, Cavallo A, Giannelli A (2015) Exploring the role of farmers in short food supply chains: the case of Italy. Int Food Agribusiness Manag Rev 18(2):109-129

Mastronardi L, Marino D, Giaccio V, Giannelli A, Palmieri M, Mazzocchi G (2019) Analyzing alternative food networks sustainability in Italy: a proposal for an assessment framework. Agric Food Econ 7(1):1-19

Mauss M (2007) In: Weber F (ed) Essai sur le don : forme et raison de l'échange dans les sociétés archaïques. 1re éd. Presses universitaires de France, Paris

Micheels ET, Boecker A (2017) Competitive strategies among Ontario farms marketing direct to consumers. Agricultural and Food Economics 5(1)

Migliore G, Schifani G, Guccione G, Cembalo L (2014) Food community networks as leverage for social embeddedness. J Agric Environ Ethics 27(4):549-567

Milestad R, Kummer S, Hirner P (2017) Does scale matter? investigating the growth of a local organic box scheme in Austria'. Journal of Rural Studies 54:304-313

Mincyte D (2012) How milk does the world good: vernacular sustainability and alternative food systems in post-socialist Europe'. Agriculture and Human Values 29(1):41-52

Moulaert F, MacCallum D, Hillier J (2013) Social innovation: intuition, precept, concept, theory and practice. In: Moulaert F, MacCallum D, Mehmood A, Hamdouch A (eds) The international handbook on social innovation collective action, social learning and transdisciplinary research. Edward Elgar Pub. Ltd, Cheltenham, pp 14-24

Naylor L (2012) Hired gardens and the question of transgression: lawns, food gardens and the business of "alternative" food practice. Cultural Geographies 19(4):483-504

Organic research center. 2016. Soil association's organic market report reveals growth of 4.9\% in 2015 .

Paül V, Mckenzie FH (2013) Peri-urban farmland conservation and development of alternative food networks: insights from a case-study area in Metropolitan Barcelona (Catalonia, Spain). Land Use Policy 30(1):94-105

Polanyi K (2012) In: Polanyi-Levitt K (ed) A Subsistência Do Homem e Ensaios Correlatos. Contraponto, Rio de Janeiro

Przepiorka W (2014) Reputation in offline and online markets. Econ Soc Eur Electronic Newslett 16:4-10

Reardon T, Timmer C (2012) The economics of the food system revolution. Annual Review of Resource Economics 4:225

Research L (2012) Self-selection sampling

Sabourin É (2011) Políticas Públicas de Desenvolvimento Sustentável e Reciprocidade. Raízes 31:9-24

Sabourin É (2012) Organisations et sociétés paysannes : une lecture par la réciprocité. Éd. Quae, Versailles

Si Z, Schumilas T, Scott S (2015) Characterizing Alternative Food Networks in China. Agriculture and Human Values 32(2):299-313

Smith J, Jehlička P (2013) Quiet sustainability: fertile lessons from Europe's productive gardeners. Journal of Rural Studies 32(C):148-157

Soil Association. 2014. Organic Market Report 2014. Bristol.

Som CR (2015) Alternative food networks and food provisioning as a gendered act. Agriculture and Human Values 32(3):461-474

Spilková J, Fendrychová L, Syrovátková M (2013) Farmers' Markets in Praque: A New Challenge within the Urban

Shoppingscape. Agriculture and Human Values 30(2):179-191 
Stevenson GW, Ruhf K, Lezberg S, Clancy K (2007) Warrior, weaver and builder work. In: Hinrichs CC, Lyson TA (eds) Remaking the North American food system : strategies for sustainability. University of Nebraska Press, Lincoln, pp 368-705

Sykes KM (2005) Arguing with anthropology an introduction to critical theories of the gift. Routledge, London

Thilmany D (2008) Going local: exploring consumer behavior and motivations for direct food purchases. American Journal of Agricultural Economics 90(5):1303-1309

Thorsoe M, Kjeldsen C (2016) The constitution of trust: function, configuration and generation of trust in alternative food networks. Sociologia Ruralis 56(2):158-175

Tongco MDC (2007) Purposive sampling as a tool for informant selection. Ethnobotany Research \& Applications 5:147-158

Tregear A (2011) Progressing knowledge in alternative and local food networks: critical reflections and a research agenda. Journal of Rural Studies 27:419-430

Tremblay D-G, Fontan J-M, Klein J-L (2009) Initiatives locales et développement socioterritorial. Télé-université, Québec

Vermeir I, Verbeke W (2006) Sustainable food consumption: exploring the consumer "attitude - behavioral intention" gap. Journal of Agricultural and Environmental Ethics 19(2):169-194

Vidal F, López DB, Del Campo FJ (2011) Analysis of the Relation between Organic Products Consumption and Box Schemes Use in Alicante (Spain). Agricultural Sciences 02(04):505-510

Vitters $\varnothing$ G, Tangeland T (2015) The role of consumers in transitions towards sustainable food consumption. The Case of Organic Food in Norway. J Cleaner Production 92:91-99

Wang R, Si Z, Ng C, Scott S (2015) The transformation of trust in China's alternative food networks: disruption, reconstruction, and development. Ecol Soc 20(2)

Warde A (1997) Consumption, food and taste: culinary antinomies and commodity culture. Sage, London

Wilkinson J (2010) Economic and Agrofood Studies in Brazil. Econ Sociol Eur Electronic Newslett 11:3-9

Wilson AD (2013) Beyond alternative: exploring the potential for autonomous food spaces. Antipode 45(3):719-737

Yin RK (2014) Case study research : design and methods, 5th edn. Sage Publications, Thousand Oaks

\section{Publisher's Note}

Springer Nature remains neutral with regard to jurisdictional claims in published maps and institutional affiliations.

\section{Submit your manuscript to a SpringerOpen ${ }^{\circ}$ journal and benefit from:}

- Convenient online submission

- Rigorous peer review

- Open access: articles freely available online

- High visibility within the field

- Retaining the copyright to your article

Submit your next manuscript at $>$ springeropen.com 